Fecha de recepción: 05-06-2019

Fecha de aceptación: 10-07-2019

Fecha de publicación: 15-07-2019

Para citar este artículo: Martínez Moscoso, A. (2019). La regulación del abastecimiento de agua en Ecuador. Evolución histórica y realidad actual. Sostenibilidad: económica, social y ambiental, 1, 31-54. https://doi.org/10.14198/Sostenibilidad2019.1.03

\title{
La regulación del abastecimiento de agua en Ecuador. Evolución histórica y realidad actual
}

\section{The drinking water process regulation in Ecuador. Historic evolution and current reality}

\author{
Andrés Martínez Moscoso \\ Coordinador del Grupo de Investigación "Water Law and Management Lab" \\ Universidad de Cuenca, Ecuador \\ andres.martinez@ucuenca.edu.ec \\ https://orcid.org/0000-0002-8952-0680
}

\section{RESUMEN}

Las características geográficas, las condiciones climáticas, la biodiversidad, el multiculturalismo y la historia han influido de manera determinante en el abastecimiento de agua en Ecuador. El artículo, a través de un enfoque histórico, explora los acontecimientos más importantes de la provisión del líquido vital desde los pueblos aborígenes hasta la actualidad, poniendo especial énfasis en la regulación jurídica. Para lo cual se detiene en las tres ciudades principales del Ecuador, desde una visión de los gobiernos locales y la subsidiariedad, demostrando que pese a ser un país pequeño, incluso desde el modelo de gestión se han usado diferentes visiones adaptadas a las ideologías de los gobernantes y como repercusión de los acontecimientos políticos e históricos de la época. Teniendo especial importancia el artículo, porque por primera vez se enfoca la gestión del agua en el Ecuador no a través de una visión bicentralista (Quito y Guayaquil), sino se incluye a la tercera ciudad de la República.

Palabras clave: abastecimiento; regulación; Quito; Guayaquil; Cuenca; Ecuador. 


\begin{abstract}
The water supply in Ecuador had been influenced by their geography, the weather, the biodiversity, multiculturalism and the history. The paper uses an historic perspective and explore the most important facts of the water supply process since indigenous people from current time, which special focus in the regulation and normative facts. The documents concentrated its study in the three most important Ecuadorian cities, using a local government and subsidiary perspective, to try to demonstrate that even in a small country, there are different management models which have been adapted from different ideologies, and political and historic events. The paper has a special importance because it's the first time which the water management use a different perspective, not only the classic (bicentralism from Quito and Guayaquil), because it includes the third city of the country.
\end{abstract}

Keywords: Water; water supply; Quito; Guayaquil; Cuenca; Ecuador.

\title{
1. Introducción
}

Al igual que el resto de las civilizaciones, las poblaciones aborígenes que se asentaron en lo que actualmente es el territorio de la República del Ecuador, lo hicieron junto a importantes fuentes de agua: deshielos del volcán Pichincha en Quito, el río Daule en Guayaquil, y los 4 ríos (Tomebamba, Yanuncay, Tarqui y Machángara) de Cuenca.

Situación que fue aprovechada tanto durante la conquista incásica y española, respectivamente, cada uno de ellos con el mejoramiento de los procesos para el abastecimiento, así como incorporaciones en relación con traslado de aguas y saneamiento.

Sin embargo, los gobiernos locales siempre han sido los encargados de imprimir una especial impronta en cada uno de los modelos de gestión, de tal suerte, en un país tan pequeño, existen múltiples formas a través de la gestión pública, privada e incluso comunitaria, propia de los pueblos y nacionalidades indígenas.

Desde una perspectiva jurídica, la evolución de la regulación de las aguas ha vivido por lo menos tres grandes momentos: un primero, asociado a una concepción del recurso hídricos desde una perspectiva privada, a través de la cual los individuos eran propietarios de los derechos de agua otorgadas por el Estado; una segunda, en la cual pasa a el agua a ser un patrimonio público y por ende tutelado por el Estado; y, una tercera, desde la visión del agua como un derecho humano y fundamental.

El trabajo utiliza una metodología de análisis desde la perspectiva histórica jurídica de las instituciones que regulan la gestión del agua, para lo cual se escogen tres ciudades representativas del país, Quito y Guayaquil, capital y puerto principal de la nación, pero se incluye además a Cuenca, dada su connotación en relación a la calidad de sus servicios públicos, así como por representar a la mayoría de los municipios intermedios del Ecuador.

Se utiliza los aspectos históricos más representativos en relación a la gestión del agua en cada una de las ciudades escogidas, y se realiza un recorrido desde los pueblos aborígenes, el incario, la colonia, la república hasta llegar a la era moderna.

Además, se destaca la normativa y regulaciones más representativas de la época, en la que se evidencia el rol fundamental de los recursos hídricos en la evolución de los pueblos, y cómo se ha generado una interdependencia como este importante recurso. 
El artículo finaliza con un acercamiento a la regulación del agua desde la última Constitución (2008), y destaca los principales enfoques, características y visiones que el constituyente ecuatoriano tuvo con el propósito de garantizar al agua como derecho humano y fundamental, a la vez que lo consideró como necesario para la realización del resto de derechos (salud, educación, alimentación, etc.).

\section{La visión del Estado, los recursos naturales y el agua en la historia del Ecuador}

\subsection{Pueblos aborígenes e incario}

El territorio que actualmente se encuentra asentado el Ecuador, es el resultado del paso de un sin número de culturas, nacionalidades indígenas y realmente un verdadero encuentro de pueblos, producto de los cuales nació un Estado con sus particularidades en el plano geográfico dada su megadiversidad, su privilegiada posición geográfica, atravesada por la línea equinoccial, pero sobre todo sus ciudadanos que son la muestra fiel del sincretismo y de la plurinacionalidad.

Previo a la conquista incásica y posterior española, los pueblos originarios que habitaban la región mantuvieron siempre una especial conexión con la naturaleza, al igual que en otras culturas alrededor del mundo designaron como sus divinidades al Sol conocido como Inti, a la Luna como Killa, a la fuerza Pachacamac, y a la madre tierra la Paccha Mama; teniendo una significativa repercusión en rituales, y sobre todo en la cosmovisión andina que ha sido rescatada en los últimos tiempos durante los procesos constituyentes americanos del último siglo.

Durante la conquista incásica (el período Inca el modelo basado en el Imperio y el gobierno total del Inca sobre sus súbditos, tuvo una evidente repercusión en la forma de administrar los actuales territorios del Ecuador, pues dada su forma de expansión y conquista, los Incas procedían a través de la imposición, borrando todo signo previo que les hubiese pertenecido previamente a las culturas Cañarís, Paltas, Quitus, Puruhaes, Manteño, Huancavilcas u otras.

Tabla. 1. La Cosmovisión Andina del Agua. Fuente: elaboración propia, a partir de Huanacuni Mamani (2010, pp. 87-88).

\begin{tabular}{|l|l|l|}
\hline \multicolumn{3}{|l|}{ La Visión de los pueblos andinos originarios sobre el Agua } \\
\hline & Los Principios & El Alcance \\
\cline { 2 - 3 } & Como ser vivo & Proveedor de vida (no es un recurso. Objeto) \\
\cline { 2 - 3 } & Como ser sagrado & $\begin{array}{l}\text { Proviene de Viracocha/Huiracocha (Deidad) y } \\
\text { emerge de la Pacha Mama (Madre Naturaleza). }\end{array}$ \\
\cline { 2 - 3 } $\begin{array}{l}\text { YAKU } \\
\text { (Kichwa }\end{array}$ & $\begin{array}{l}\text { Como base de la reciprocidad y } \\
\text { de la complementariedad }\end{array}$ & $\begin{array}{l}\text { Integración de todos los seres y articulación de } \\
\text { la naturaleza. }\end{array}$ \\
\cline { 2 - 3 } Ecuador) & $\begin{array}{l}\text { Como derecho universal y } \\
\text { comunitario }\end{array}$ & $\begin{array}{l}\text { Pertenece a todos. No es posible su } \\
\text { privatización. }\end{array}$ \\
\cline { 2 - 3 } & $\begin{array}{l}\text { Como expresión de la } \\
\text { flexibilidad y la adaptabilidad }\end{array}$ & $\begin{array}{l}\text { No tiene normas rígidas, se adapta al } \\
\text { ecosistema. }\end{array}$ \\
\cline { 2 - 3 } & $\begin{array}{l}\text { Como ser creador y } \\
\text { transformador. }\end{array}$ & Dimensión equilibradora en todos los planos. \\
\hline
\end{tabular}

\footnotetext{
${ }^{1}$ Huanacuni Mamani, señala que en Bolivia se considera también como la "sangre" de la tierra.
} 
No hay que olvidar que el dominio Inca fue de tan sólo de un siglo (1438-1533), lo cual significa que el resto de tiempo los pueblos aborígenes tuvieron otra organización, administración y manejo, mas, con el "encuentro ${ }^{2 "}$ " con los españoles, la poca identidad que quedaba fue borrada en la mayor parte de casos de manera violenta y bajo el amparo y bendición en todo momento de la jerarquía y miembros, de la Iglesia Católica.

En consecuencia, para el aborigen o indígena latinoamericano sus tierras y su manera de ver el mundo cambio totalmente en pocos años, cambiándola totalmente y adaptándola a una realidad que no era la suya, bajo unos códigos y parámetros occidentales europeos que le eran ajenos y sobre todo impuestos. Todo esto generó la exclusión de este pueblo que, en lugar de reaccionar, fue quedándose callado y acostumbrándose al cambio.

\subsection{El período colonial y el republicano}

Los actuales territorios de lo que hoy conforman el Ecuador durante el período colonial formaron parte del Virreinato de Lima, y su capital fue la ciudad de Lima, mientras que en el plano administrativo se adscribió a la Real Audiencia de Quito, la cual jerárquicamente constituía una división de menor grado, lo cual le suponía incluso limitada comunicación directa con el Reino de España.

Luego de años de la mala administración realizada por los chapetones ${ }^{3}$, sumada a la prepotencia de los criollos ${ }^{4}$, existieron las razones suficientes para que los mestizos apoyados por fuerzas inglesas (con su financiamiento), hicieron que los primeros cantos de independencia en América sean posibles, y de manera particular en Quito, donde el 2 de agosto de 1809 se proclamó el primer grito de Independencia.

Sin embargo, el problema desde el punto de vista de gobernanza, fue que en lugar de un dominador (Corona española) llegó un nuevo liderado por ejércitos criollos y mestizos, los cuales desde 1830 en base a su papel en el movimiento libertario, buscarían ya un protagonismo y sobre todo un espacio de poder; "...el proceso de "independencia" republicana fue promovido y controlado por la misma oligarquía criolla, que únicamente, pretendía mantener sus particulares privilegios... por tanto no hay la intención de cambiar la estructura exclusión, marginación y subordinación económica, política y discriminación” (Llasag, 2008, p. 313).

En el caso ecuatoriano, no se puede olvidar la participación que este tuvo en la conformación del sueño de Simón Bolívar de la construcción de la Gran Colombia, la cual sería un bastión de resistencia desde el Sur frente a la potencia que se creaba en el Norte con Estados Unidos de América. Pero la ilusión no prosperó, producto de las gestiones realizadas y debido al centralismo ${ }^{5}$ que desde ese momento se puso al proyecto, así como a la traición que tuvieron los generales bolivarianos que buscaban su espacio de poder a nivel local.

\footnotetext{
${ }^{2}$ Los actuales historiadores consideran que no se trató de un descubrimiento, sino más bien de un encuentro entre dos culturas. Pues los aborígenes que habitaban lo que hoy se conoce como el continente americano mantenían ya contactos e incluso operaciones comerciales con otros pueblos del Pacífico, razón por la que técnicamente el 12 de octubre de 1492, no puede ser considerado propiamente un descubrimiento, según algunos autores.

${ }^{3}$ Colonizadores llegados de España

${ }^{4}$ Hijos de españoles nacidos en América.

${ }^{5}$ El autor ecuatoriano, Efraín Pérez (2009), considera que a diferencia de quienes afirman que durante la Colonia se implementó un modelo centralista; éste señala que con la lejanía del poder central, fueron precisamente los cabildos abiertos la más pura y genuina forma democrática y popular de la administración local.
} 
De esta manera, la presencia militar desde el inicio de la era Republicana en Ecuador, fue un reflejo y una sombra que le seguirá durante toda su historia en cada uno de los movimientos de ruptura del orden constitucional.

\subsection{Disputa territorial: centralismo y bicentralismo}

En Ecuador, son claramente distinguibles cuatro regiones geográficas, la Costa donde su ciudad emblemática es la capital de la provincia del Guayas, el puerto de Santiago de Guayaquil; la Sierra identificada con la cordillera de los Andes, en la cual se encuentra la capital de la República, San Francisco de Quito; y al Sur la ciudad histórica de Santa Ana de los ríos de Cuenca; la tercera región es la selva amazónica; y la cuarta constituye el archipiélago de Galápagos.

Durante finales del siglo XIX e inicios del XX, la gran disputa dentro del país se concentró entre las dos regiones, Costa y Sierra, traducidas en los conflictos Guayaquil versus Quito, desde el plano económico, administrativo, modelos de gestión, entre otros.

Uno de los mayores reclamos y fundamentos para la protesta en contra del centralismo se tradujeron de la propia organización y composición del Estado, lo cual sumado al aislamiento natural que suponía flanquear la cordillera de los Andes para llegar a la Costa, se tradujo en una incomunicación entre las grandes ciudades.

En consecuencia, Guayaquil se comunicaba vía marítima más con otras grandes capitales latinoamericanas que con su propia capital, Quito. Situación que se tradujo además en el ámbito ideológico, la Costa con un modelo agroexportador liberal, mientras que la Sierra en uno conservador asociado a los grandes latifundios y haciendas.

A inicios del siglo XX, se produjo la Revolución Liberal (1905), la cual supuso un cambio radical en la forma de concebir el Estado, con la aplicación de los principios liberales, con la consecuente instauración de un Estado laico, otorgando mayores derechos a los ciudadanos y una novedosa forma de administrar la cosa pública lo cual supuso un proceso de modernización, con la construcción de centrales eléctricas e incluso la construcción del ferrocarril que conectaría por fin la Sierra y la Costa.

Hasta la mitad del siglo XX fue evidente la pugna que quedó entre conservadores y liberales, sin una real participación por parte de la población.

Durante la década de los setenta del siglo pasado, existió la ruptura del orden constitucional so pretexto de garantizar la estabilidad y las instituciones por parte del ejército ecuatoriano ${ }^{6}$, los cuales a través de largos períodos de dictadura gobernaron al país, con serias consecuencias a la democracia ecuatoriana, la cual se vio afectada durante décadas posteriores, debido a este fenómeno de inestabilidad y de privilegio de la fuerza sobre la razón democrática hasta la consolidación de la democracia en 1978.

\footnotetext{
${ }^{6}$ A criterio de Jorge Carpizo, el presidencialismo latinoamericano se define "...como aquel caracterizado por un estricto predominio del presidente, y un papel importante asumido por el ejército" En (Quiroga Lavié, 1991, p. 265). Situación que refleja la fragilidad de las democracias y un poder armado oculto.
} 


\subsection{La regulación del agua en Ecuador: perspectiva histórica}

Dentro de la legislación de gestión de aguas, existen dos modelos claramente diferenciados: el primero, permite que esta sea administrada desde un punto de vista privado, con la correspondiente aparición de los mercados de agua; y, el segundo, aquel en el cual el Estado, a través de distintos niveles de gobiernos se encarga de su gestión pública.

El caso ecuatoriano en el último siglo ha atravesado por las dos visiones, primero una que podríamos llamar civilista, en la cual hasta 1960, la administración del agua se mantuvo como propiedad privada, en este sentido, el gobierno central se manifestaba simplemente con el propósito de solución de controversias y concesiones de uso, teniendo el ejercicio de la competencia a través del Ejecutivo, con uno de sus Ministerios, primero a través de Fomento y posteriormente a cargo de Agricultura.

No obstante, con la promulgación de la Ley de 1960, el agua se reguló como un bien nacional, categoría que se mantuvo en las reformas de 1972, donde se declaró a todas las aguas continentales del país de dominio público.

La gobernanza del agua entró a debate en la década de los setenta del siglo pasado, debido a la importancia que esta tuvo durante la Reforma Agraria, dentro del cual se dividieron importantes latifundios del país con el propósito de promover la agricultura de manera particular entre comunidades campesinas y pueblos indígenas.

Estos actores requerían del líquido vital para producir las tierras que les fueron asignadas. Pese a ello, se generó una importante política de subsidios y condonación de deudas focalizado en estos colectivos, sobre todo por aspectos relacionados con política clientelar.

Frente a ello, la gestión del agua potable seguía manejada por los gobiernos locales (municipios), que concentraban su gestión en las zonas urbanas, dejando a las zonas rurales desatendidas.

Producto de ello, con base en la gestión comunitaria, los pueblos y nacionalidades indígenas, así como grupos de campesinos organizados crearon las Juntas de Agua Potable, y de Riego, respectivamente; figuras legales basadas en la asociatividad, y que tienen por propósito la colaboración para la obtención de recursos hídricos para sus asociados. Si bien es cierto se cumplió con el acceso al agua, esta presenta serios problemas en relación con su calidad.

Con la llegada del proceso de Modernización del Estado (1993) y su correspondiente normativa, esta afectó a la prestación de los servicios públicos de manera particular, debido a su intención de resolver los problemas económicos y de eficiencia, siendo en el caso del agua potable y saneamiento, delegada su gestión primero al Ministerio de la Vivienda, y posteriormente al Consejo Nacional de Recursos Hídricos (1994) (Pigretti, Dino Bellorio y Carvalli, 2010).

Cabe señalar que, durante este proceso, existió una apertura a la participación privada en la prestación de los servicios públicos, lo cual se vio sobre todo en los cantones de la Costa del Ecuador, entre los más importantes el de Guayaquil, Machala, Samborondón, entre otros. 
Desde la aprobación de la Constitución de la República (2008) ${ }^{7}$, el Estado es el protagonista en la gestión del agua, siendo el encargado de garantizar la conservación, recuperación y manejo integral de los recursos hídricos, cuencas hidrográficas y caudales ecológicos asociados al ciclo hidrológico. Además, regula toda actividad que pueda afectar la calidad y cantidad de agua, así como el equilibrio de los ecosistemas, en las fuentes y zonas de recarga de agua (art. 411). Mediante una autoridad a cargo de la gestión del agua, el Estado es responsable de su planificación, regulación y control (art. 412). No obstante, la gestión se restringió a la esfera pública (municipal) y comunitaria, dejando de manera excepcional la posibilidad de la intervención privada.

\section{La gestión del agua en las principales ciudades de Ecuador}

\subsection{El agua en Quito}

La ciudad de San Francisco de Quito, es la capital de la República del Ecuador, con una altitud de 2850 metros sobre el nivel del mar, msnm, siendo su máxima los $4794 \mathrm{msnm}$ en el volcán Pichincha. Su orografía se caracteriza por grandes pendientes así como quebradas y laderas, presentándose superficies planas en los valles.

El Distrito Metropolitano de Quito, lo conforman a su vez: la ciudad de Quito (con 33 parroquias urbanas), y las 33 parroquias rurales, teniendo una extensión aproximada de 4.228 kilómetros cuadrados.

Al encontrarse en la cordillera de Los Andes, el período de lluvias es severo y afecta de manera constante a la ciudad, presentándose sobre todo inundaciones y deslaves. Así también al encontrase en las faldas de un volcán, se han producido algunas erupciones ${ }^{8}$, siendo la más reciente la acaecida en octubre de 1999, cuando la ceniza cubrió la ciudad.

Los aborígenes que se asentaron en lo que hoy se conoce como Quito, buscaron el abastecimiento de agua corriente, a través de los deshielos del volcán Pichincha y Atacazo, así como en el resto de fuentes de agua que nacían de las montañas colindantes. Tal como lo señala Ortiz Crespo (2014), la localización de Quito, en medio de los Andes fue un factor fundamental para que los antiguos habitantes se asienten en esta zona, ya que gracias a ello pudieron constituirse en un importante lugar de intercambio de productos.

Los primeros pobladores supieron aprovechar de manera inteligente el recurso hídrico, tanto como para consumo humano, así como para el riego en beneficio de la agricultura.

Para explicar lo sucedido con la evolución del agua potable y el saneamiento en Quito, es necesario referirse a por lo menos a seis períodos (Zary, 2009):

a) El Período aborigen, preinca. En el que por lo menos tres grandes vertientes proveían de agua al territorio que ahora se conoce como Quito, lo cual hace pensar que la decisión de los aborígenes de asentarse en la misma no fue fruto de la casualidad, sino que

\footnotetext{
${ }^{7}$ La disposición transitoria Vigésimo Séptima (2008), dispuso la realización de una auditoría financiera, jurídica, ambiental y social de las delegaciones a empresas privadas. Con el fin de renegociar o terminar los contratos suscritos, para todo lo cual dio un plazo de 360 días para su cumplimiento.

${ }^{8}$ Tal como lo señalan Jarrín \& Landazuri (2014), no sólo el Pichincha afectó a la ciudad de Quito con sus erupciones, sino también el volcán Cotopaxi en 1744, 1768 y 1877, respectivamente.
} 
dichas quebradas: 24 de mayo (Ullanguaga-huayco), (Huanacauri y Pilishuaico) Sanguña y El Tejar, y San Blas, proveían limpias aguas y con una corriente considerable, lo cual es confirmado por el historiador Luciano Andrade Marín; así también, el resto de acequias fueron reconducidas a un gran canal con el propósito de proveer del líquido vital a sus palacios y demás construcciones, tanto para uso doméstico de consumo, así como para riego.

El agua no fue considerada tan sólo como un recurso, sino que desde la concepción andina, el agua o "Yaku" se relacionaba con la "Pacha Mama" (madre tierra) y era tanto una deidad así como fundamental para sus rituales de purificación (baño ritual, o, el baño por el matrimonio), de castigo (agua fría y ortiga), sanación, entre otros. Situación que se mantiene hasta la fecha en los pueblos indígenas descendientes que pueblan Ecuador, así como en la mayoría mestiza a través de los ritos católicos vinculados con el agua.

b) El período del Incario. Una de las fortalezas que tuvo el Imperio fue el perfeccionamiento en la construcción de infraestructuras (véase el camino del Inca o Capac Nan o Qhapaq Nan, red vial incaica empedrada de 5200 kilómetros de longitud), entre las cuales se encontraban las terrazas, así como los canales de conducción de agua, los cuales durante años fueron puestos a prueba a lo largo del Tahuantinsuyo.

Si bien la presencia Inca en la zona del actual Quito fue corta, tuvieron el tiempo suficiente para mejorar los sistemas de provisión de agua sobre todo para sus grandes palacios. Tal como lo señala el historiador Andrade Marín, en donde hoy se levanta la Iglesia de San Francisco, se encontraba el palacio imperial, conocidas como "casas de placer", en las cuales precisamente se contaba con abastecimiento de agua para consumo tanto para la realeza, así como para sus acompañantes.

Situación corroborada por, Cecilia Ortíz (2014, p.272), quien señala que: "La tradición oral y escrita ha recogido sobre el barrio El Placer a lo largo de la historia, la función de sitio de descanso del Inca Huayna Cápac. Según cuentan las crónicas, allí se hallaban las casas "de placer" del "Señor Natural", en la falda del cerro".

c) El período colonial. A más de las construcciones que el ejército español encontró a su llegada, la provisión de agua no fue un problema, dados los sistemas creados previamente por los incas, que pese a la destrucción que se dio durante las batallas, muchas infraestructuras subsistieron, entre las que se encontraban los "vircus" (canales de conducción de agua), así como los “ojos de agua", pequeños pozos situados en la falta del volcán Pichincha (Zury, 2009).

Las crónicas de la época recogen esta situación: “el agua que venía del Pichincha desde el principio de la Colonia se distribuía hacia las pilas, de donde los habitantes de la ciudad se abastecían para las casas y huertas y que junto a una red de tuberías o caños constituían la red de aprovisionamiento de la ciudad" (Landazuri, 2014).

Mientras que el Cabildo Municipal tuvo potestades sobre los recursos hídricos, destacándose: a) legislar sobre las aguas, ríos, lagos, etc., (1535), de tal forma intentó regular el consumo de agua estableciendo límites e incluso sanciones; b) se encargaban de la distribución del agua y mantenimiento (reconstrucción) de los canales, lo cual resultaba ser una verdadera carga dados los problemas de taponamientos que tenían los desagües; c) decidir las fuentes de agua de aprovisionamiento para la ciudad (Luzuriaga Jaramillo, 2013). 
d) El período republicano. Con la llegada de la República (1830), los asentamientos humanos se extendieron considerablemente y la provisión de agua fue cada vez menor, ya que la mayor parte de canales que se construyeron en el pasado se contaminaron de manera constante producto del mal uso que la población hacía al depositar basura y desperdicios ${ }^{9}$.

En este contexto, las familias acomodadas en Quito y Latinoamérica (Keneddy Troya, 2005), con el propósito de abastecerse de agua limpia optaron por contratar los servicios de los "aguadores" o "aguateros", indígenas que luego de caminar varios kilómetros obtenían agua de mejores condiciones de los manantiales y fuentes de la zona, y cargaban a su espalda en grandes recipientes de cerámica denominados "pondos” (Fuentes Roldán, 2007).

La contraprestación económica fue muy baja, debido a las relaciones inequitativas que existían con los indígenas, con una constante de abusos de los intereses de los aguadores. Durante mucho tiempo estos personajes que formaron parte de la realidad de las ciudades de aquel entonces, brindaron un servicio fundamental, pues debían llevar la pesada carga, pase lo que pase, o pese lo que pese. (Zury, 2009).

e) El proceso de modernización (siglo $\mathrm{XX}$ ). El siglo $\mathrm{XX}$ trajo consigo la gran expansión de la ciudad de Quito, lo cual obligó a sus autoridades a la correspondiente prestación de los servicios básicos tanto en cantidad (cobertura), así como en calidad.

En el primer cuarto de siglo destacan los siguientes acontecimientos en ésta materia: i) Ley de creación del fondo de agua potable y canalización, financiada a través de un impuesto al aguardiente (1902); ii) Impuesto a la producción del cuero, fondos adicionales agua potable y canalización; iii) Se contratan los estudios para la dotación de estos servicios básico con el profesional alemán, Vernimenn; iv) El gobierno retira los fondos de agua potable y canalización (1906); v) Para suplir el desfinanciamiento provocado, el General Eloy Alfaro declara obra de carácter nacional la dotación de agua potable y canalización para Quito, financiándolo a través de lo producido en las Aduanas; vi) Para que sea operativo el fondo, se crea la Junta de Agua Potable y Canalización de Quito (1906); vii) Se inicia la construcción de la primera planta potabilizadora (1908), terminada en 1910; viii) Construcción de la planta potabilizadora de "El Placer" (1912); ix) El decreto legislativo de 26 de octubre de 1915, señala que el Municipio debía asumir la prestación del servicio de agua potable; x) A mediados de siglo se produce un déficit en la provisión de servicios, cercano a 360 litros por segundo (1946), lo cual se traducía en baja presión e intermitencia en el servicio, incluso muchos barrios eran abastecidos a través de camiones cisterna; xi) Se contrata a la firma estadounidense Harold T. Smith, con el propósito de elaborar un informe de la situación del agua potable y saneamiento en la ciudad y la correspondiente construcción de obras (década de los cuarenta); xii) Se expide la Ordenanza para la reglamentar el uso y consumo de agua potable en Quito (1952); xiii) Gracias a las sugerencias de la consultora estadounidense Harold T. Smith, el Concejo Municipal declaró de uso público el agua de la ciudad (1953) y se recomendó cobrar por el servicio de agua potable, a través del establecimiento de unas tarifas, todo ello con el propósito de contar con liquidez para la operación y mantenimiento del sistema, así como para la construcción de nueva infraestructura.

\footnotetext{
${ }^{9}$ Eduardo Kingman Garcés, en su obra "La ciudad y los otros Quito 1860-1940. Higienismo, ornato y policía", (2006, p. 14), al referirse al Quito del siglo XIX, señala: "La ausencia de servicios de alcantarillado, de agua potable, la suciedad de las calles y de las plazas, el desaseo de las habitaciones, y el "primitivismo de las costumbres", eran aspectos destacados por los viajeros en sus descripciones de la ciudad".
} 
f) La creación de una empresa para la provisión del servicio de agua potable. En 1960 (a través de Ordenanza No. 932, de 13 de junio se creó la Empresa Municipal de Agua Potable), mientras que en el caso del alcantarillado fue en 1966 (Ordenanza No. 1118).

La creación coincidió con el desarrollo urbanístico de la urbe y la correspondiente expansión hacia las zonas suburbanas ${ }^{10}$. En noviembre de 1993 se realizó la fusión de las dos anteriores en la Empresa de Agua Potable y de Alcantarillado de Quito, EMAAP-Q (Ordenanza No. 3057).

Desde 2008, con los cambios introducidos por la Constitución de la República (2008) y la Ley Orgánica de Empresas Públicas (2009), en 2010 se creó la Empresa Metropolitana de Agua Potable y Saneamiento, EPMAPS EP

Las estadísticas de cobertura que cuenta el DM de Quito, para dimensionar los cambios vividos ${ }^{11}$ en las últimas décadas, pues en 1968 era de 48\%, en 1980 el 51\%, en 1990 el 77,5\%, en el 2001 el 89,3\% y en el 2014 es ya del 98,4\% (EPMAPS, 2014).

\subsection{El agua en Guayaquil}

La ciudad de Santiago de Guayaquil, y su respectivo cantón es el más importante de la provincia del Guayas, situada a orillas del río del mismo nombre. La cuenca baja del río Guayas es susceptible de inundaciones dado su relieve, al tratarse de valles, terrazas fluviales y llanuras, todas ellas con una pendiente inferior al 12\% (IGM, 2013, p. 31). El cantón se encuentra a conformado por 17 parroquias urbanas y 5 parroquias rurales; siendo la ciudad de Guayaquil la más poblada con 2.291.158 habitantes.

Durante el siglo XVIII, la población guayaquileña no superaba las 6.500 personas, con lo cual bastaba el abastecimiento a través de los pozos de agua ubicados al pie del Cerro Santa Ana, y cuando la demanda se incrementó, se optó por utilizar el agua del río Daule (Swyngedouw \& Bovarnick, 1994).

Al igual que lo sucedido en la capital de la República, quien se encargaba de transportar el agua en aquella época eran los "indios aguateros ${ }^{12}$ ", situación que poco a poco se fue convirtiendo en un negocio rentable, por lo cual, blancos y mestizos se ocuparon de regularlo para evitar especulaciones, pese a ello el agua entre más pura, era más costosa, con lo cual se generó una verdadera estratificación frente al agua, ya que los pobres no podían costearse agua de calidad. El servicio de aguadores se incrementó debido a los intensos procesos de urbanización, así como al elevado poder adquisitivo de la población guayaquileña debido al boom agroexportador (cacao).

Con el paso del tiempo, las élites urbanas exigieron mejores servicios, creciendo de manera desigual la ciudad, pues pese a la ingente cantidad de recursos que se invirtieron en obra pública (saneamiento, transporte e infraestructura), ésta fue canalizada sobre todo a satisfacer las

\footnotetext{
10 “Como en muchas otras ciudades, sufrió un vaciamiento de población con capacidad económica a partir de la década de 1980, y ha experimentado muchos cambios, tanto en uso, como densidad y población". (ONU-Hábitat, 2012, p. 74).

${ }^{11}$ No se puede olvidar que a diferencia de lo que suceden en otras ciudades, Quito posee un complicado sistema de captación. Así lo señala Carrillo et al (2007) "Quito... has a more complicated system of carrying water from its sources to the city and its suburbs. Hundreds of kilometers of piping are used to transport water from seven water-capture sites to 22 treatment plants", las cuales cada vez se incrementan debido al crecimiento urban y los nuevos planes de la Empresa.

${ }^{12}$ Aguatero o aguador: Persona que tiene por oficio llevar o vender agua (RAE, 2014).
} 
necesidades de la creciente clase media y alta $^{13}$, quienes se encontraban altamente influenciados por la cultura europea.

A finales del siglo XIX, se creó la primera compañía de Agua Potable (1880), pero fracasó debido al poco apoyo que tuvo por parte de los inversionistas. En 1892, se inauguró el primer reservorio en el Cerro del Carmen, el cual dotaba de servicio a través de una red pública a más de 150 domicilios (Swyngedouw \& Bovarnick, 1994).

Lo anterior demuestra que el problema de cobertura del servicio de agua potable en la ciudad se agravó en las últimas décadas del siglo XX, y no fue precisamente técnico, pues ya desde el siglo pasado a través de visionarios guayaquileños y técnicos europeos, se pudo desarrollar un sistema de agua y saneamiento, bastante aceptable, que incluso a inicio del siglo XX superó la cobertura de algunas ciudades europeas.

En este sentido, como lo recoge Eduardo Kingman (2006), Guayaquil desde finales del siglo XIX, era una urbe de gran importancia, incluso más que Quito, puesto que contaba con mejores servicios, lo cual es confirmado en la obra de Teodoro Wolf (1892):

Guayaquil... es sin duda alguna la principal y más importante ciudad del país, bajo todo respecto. Quito le aventaja sólo por ser capital de la República y residencia del Supremo Gobierno... El cambio y mejoramiento de Guayaquil es tan considerable, que el que ha visto la ciudad unos 25 años atrás, hoy a su regreso, apenas la conocerá. Es una gran ciudad en formación, y será dentro de poco, especialmente concluidas algún día las obras de canalización y agua potable, una de las mejores de Sudamérica.

El problema de dotación del servicio se agravó con el crecimiento desordenado de la urbe, debido a la falta de control por parte del Municipio, así como a la irrupción de proveedores privados (camiones cisterna), a quienes no les interesaba abandonar su monopolio en las zonas menos favorecidas. Situación que ocasionó un problema de "estrés hídrico", pues la demanda por parte de la población superaba el agua producida en planta.

Durante muchos años se planificaron ampliaciones del servicio, a través de consultorías de empresas extranjeras especializadas (inglesas), sin embargo, por falta de recursos y decisión política no llegaron a desarrollarse las nuevas infraestructuras, con lo cual la calidad del servicio disminuyó considerablemente.

Con la llegada de un nuevo boom agroexportador (1950), esta vez con el banano, el Estado central financió estudios y construcción de nuevos reservorios y líneas de conducción, coincidiendo que en donde se construía el reservorio, se asentaron inmediatamente los barrios residenciales de clase media y alta.

No obstante, a la par crecieron muchos barrios marginales sin servicios públicos, y dependientes de expendedores privados de agua a través de botellones o camiones cisterna.

Además, dadas las constantes crisis económicas por las cuales atravesó Ecuador durante el siglo $\mathrm{XX}$, el Estado central poco a poco se fue quedando sin recursos para cubrir esa importante brecha que quedaba respecto a la prestación del servicio, mientras que la migración del campo

\footnotetext{
${ }^{13}$ Swyngedouw \& Bovarnick, (1994, 33) citan a Rojas y Villavicencio, 1988, al señalar que en ese entonces en Guayaquil: “...las obras públicas responden a dos demandas diferenciadas: la una, que priorizaba el saneamiento de la ciudad (agua potable, canalización, relleno, etc.); y la otra, que exigía el embellecimiento y ornato del puerto con miras a la celebración del Centenario de la Independencia".
} 
hacia la ciudad se incrementaba, véase así lo ocurrido durante la crisis del cacao en la que se produce un gran éxodo rural-urbano con el consecuente asentamiento en zonas periféricas y marginales.

En el último momento vivido previo al regreso a la democracia (1978), se dio un gran impulso a la construcción de infraestructuras debido a que Ecuador se convirtió en un país exportador de petróleo, con el consecuente ingreso de petrodólares que coadyuvaron para la expansión de algunos servicios básicos. Sin embargo, después de la bonanza, vino un largo período de recesión que frenó el desarrollo de los proyectos planificados, así como la puesta en marcha de otros que se encontraban en construcción.

Un informe del Banco Mundial detalla:

un factor importante en Guayaquil para el aparecimiento de las zonas urbano-marginales fue la construcción de infraestructura vial; por ejemplo, las zonas de Bastión Popular y Flor de Bastión se crearon con el aparecimiento de la vía perimetral; adicionalmente a las zonas ya existentes como los Guasmos y Mapasingue, que han seguido poblándose, con nuevos habitantes que ocupan las áreas destinadas a recreación... (Donoso, 1998, p. 5).

Guayaquil es una ciudad de contradicciones, pues se trata de la ciudad ecuatoriana más grande, con mayores recursos económicos y con bastos recursos hídricos provenientes de los ríos Daule y Babahoyo, sin embargo, hasta la década de los noventa un alto porcentaje de la población (35\% de la población urbana carecía de la provisión de agua potable), especialmente aquellos situados en la línea de la pobreza no tenían acceso ni siquiera a agua entubada, por lo que éste importante núcleo de la población dependía de manera directa del monopolio privado de agua de tanqueros y carros repartidores quienes ofrecían agua a precio exorbitados sin ningún control $^{14}$ (Swyngedouw, Guayaquil).

Un cambio radical que vivió la ciudad y con influencia directa en la dotación del servicio fue el cambio de modelo de gestión de la ciudad, impulsado por el el ex Presidente de la República, León Febres Cordero, quien en una maniobra un tanto siu generis y poco acostumbrada en el "político de carrera", tras su mandato presidencial en la década de los ochenta, y con el fin de revitalizar a su partido político ${ }^{15}$, PSC (Partido Social Cristiano), optó por la Alcaldía de Guayaquil en 1992, obteniendo una mayoría absoluta y es quien inicia un proceso al que calificó de "Regeneración Urbana"16, el cual consistía sobre todo de dotar de infraestructura física en

\footnotetext{
14 “The residents become dependent on private water vendors, selling water door to door. The absence of an official water supply system and the problems the public water utility faces in serving the invaded settlements result in a chronic shortage of potable water, extraordinarily high-water prices charged by the private vendor and rapidly deteriorating sanitary conditions" (Swyngedouw, 1995, p. 388).

${ }^{15}$ Es claro que la Administración (Gobierno Municipal) Social Cristiana del Puerto Principal (Guayaquil), durante más de dos décadas, es inusual en un país como el Ecuador en el cual, antes de la llegada de la Revolución Ciudadana (2007-presente), los presidentes duraban pocos años. (Andrade, 2007).

${ }^{16}$ En la entrevista con Foreign Policy, el alcalde Nebot define a la regeneración urbana de la siguiente manera: "Urban regeneration led hotel businesses and malls to contribute with more regeneration. We did our part and they did theirs. People's quality of life has improved considerably; there are malls for people of all socioeconomic levels". Q\&A: Jaime Nebot, mayor. (2012). Foreign Policy, (194), 1. Disponible en: http://search.proquest.com/docview/1023250353?accountid=17192, última consulta: 11/11/2014.
} 
los barrios de la ciudad, así como mejorar la calidad de los servicios públicos, sobre todo de recolección de basura, agua potable y saneamiento, así como terminales aérea y de autobuses.

Durante sus dos períodos como alcalde (1992-1996 y 1996-2000), inició la aplicación de un modelo vinculado a la Nueva Gestión Pública, y en particular a la visión neoempresarial ${ }^{17}$, el cual fue continuado y mejorado por su sucesor, y miembro también de su partido político, Jaime Nebot Saadi (2000-2019).

Su modelo de gestión fue criticado por la utilización de privatizaciones y externalización de servicios ${ }^{18}$, autores como Xavier Andrade (2007) sostienen que la otra cara de la moneda en el proceso de regeneración urbana es la menor presencia de la ciudadanía en la construcción de los asuntos locales.

El modelo de Administración (Gobierno) implantado, consideró que la Empresa Privada no debe ser vista como un enemigo del desarrollo social, al contrario, lo vio como un aliado. Con respecto a la provisión del servicio de agua potable, se utilizó la figura de externalización de servicios (vía concesión integral), suscrita a través de contrato con la Empresa: "International Water Services", Interagua (ahora VEOLIA), por un plazo de duración de 30 años (iniciado el 11 de abril de 2001). Sin embargo, para que la concesión sea operativa, tuvo que tomarse algunas decisiones.

En 1989, frente a los problemas que se presentaban respecto al abastecimiento de agua potable, se creó la Empresa Provincial de Agua Potable del Guayas, EPAP-G, que sirvió a Guayaquil y 11 cantones más.

En el caso de Guayaquil, las deficiencias fueron tan graves, hasta llegar al punto que pusieron en riesgo la salud de las personas, en tal virtud los estudios y en particular los requerimientos dados por el Banco Mundial ${ }^{19}$, para reestructurar el sistema de agua potable y alcantarillado, exigieron la creación de una empresa autónoma, tanto administrativa, económica, financiera y operativamente, de manera exclusiva para el cantón Guayaquil.

El primer paso fue la fusión de las Empresas de Agua Potable del Guayas, EPAP-G (provincial), y la Empresa Municipal de Alcantarillado de Guayaquil, EMAG (municipal).

\footnotetext{
${ }^{17}$ Dentro de las experiencias de gestión urbana en América Latina, ONU-Hábitat (2012, p. 147), destaca la gestión empresarial y la gestión pública. Siendo la primera aquella que se caracteriza por "una mayor apuesta por el mercado y el consumidor para alcanzar el desarrollo, así como la interiorización de principios y prácticas derivadas del sector privada. En él, se privilegia el enfoque de servicios y con ello una estructura de financiamiento a partir de tasas más que de impuestos...”, identificándose entre ellos el municipio de Guayaquil.

${ }^{18}$ Xavier Andrade (2007, p. 135), explica que el modelo funciona de la siguiente manera: "El gobierno local opera mediante el establecimiento de un aparato paramunicipal de fundaciones privadas con licencia de un siglo para el arbitrario manejo del especio público. Por ejemplo, el antiguo puerto a lo largo del cual se tejió el tramado urbano originar ha sido rebautizado con una marca, «Malecón 2000», y el ingreso está limitado por reglas de admisión... El tránsito por parte de los visitantes obedece a la lógica comercial que organiza este espacio: de los shopping malls...".

${ }^{19}$ El Banco Mundial realizó el proceso de acompañamiento al proceso de concesión de los servicios de agua potable y alcantarillado de Guayaquil, cuyo propósito fue: "otorgar, por parte de ECAPAG (Empresa Cantonal de Agua Potable y Alcantarillado de Guayaquil), los servicios de agua potable y alcantarillado sanitario, bajo un contrato de concesión y los de alcantarillado pluvial, bajo otro de administración", para lo cual fue necesaria la realización de un diagnóstico que permita medir las condiciones de saneamiento de la población, en particular del $60 \%$ de ella que en ese entonces vivía en los barrio urbano marginales. (Donoso, 1998, p. 4).
} 
El 12 de agosto de 1994, se promulgó la Ley de creación de la Empresa Cantonal de Agua Potable y Alcantarillado de Guayaquil, ECAPAG ${ }^{20}$, (Decreto-Ley No. 08), organismo apolítico para evitar los problemas vividos anteriormente, para lo cual debía guiarse con criterios de eficiencia administrativa.

En Art. 3, se dejó abierta la posibilidad para que ECAPAG, pueda contratar con empresas privadas la ejecución de actividades que creyese conveniente para alcanzar la eficiencia.

Debido a las denuncias de corrupción y la dependencia de ayudas económicas y transferencias del Estado Central ${ }^{21}$, se realizó un proceso de reingeniería del talento humano, con el fin de priorizar al capital humano, y excluir a quienes estaban únicamente por razones políticoclientelares.

El verdadero propósito de ECAPAG, fue aplicar un proceso estratégico de modernización del servicio público de agua potable y de alcantarillado, pues el 15 de marzo de 1995, el Consejo de Administración autorizó delegar al sector privado la prestación de los servicios de agua potable, alcantarillado y drenaje pluvial del cantón Guayaquil, a través de la figura de la concesión, prevista en la Ley de Modernización del Estado, Privatizaciones y Prestación de Servicios Públicos por parte de la Iniciativa Privada (1993).

Los beneficios que se pensaron obtener fueron: a) la tecnología de punta aplicada que permita mejorar la eficiencia operativa; b) la rehabilitación de infraestructuras y construcción de nuevas, a través de inyección de capital privado; c) desterrar el manejo político clientelar en la prestación del servicio (EMAPAG-EP, 2014).

En el año de 1997, a través del Banco Interamericano de Desarrollo, BID, se firmó un contrato de préstamo $^{22}$ con la República del Ecuador por cuarenta millones de dólares (ECUADOR (1026/OC-EC), con el fin de mejorar la prestación de los servicios de agua potable y alcantarillado en la ciudad de Guayaquil, a través de la participación del sector privado por medio de una concesión.

\footnotetext{
${ }^{20}$ La nueva empresa ECAPAG (1994) asumió todas las obligaciones legales o contractuales que tenían EPAP-G y EMAG, en particular aquellas con el Banco Mundial, el BID, entre otros organismos financieros internacionales. Paralelamente se tuvo que traspasar a las Empresas Cantonales los bienes y activos que se encontraban fuera del cantón Guayaquil, ya que la nueva Empresa tenía competencia únicamente municipal.

21 "The dependence on national finance takes the form of annual subventions and/or ad hoc and often ex post facto 'emergency' subsides or loans. This dependence leads to a situation in which urban water supply is caught in the political debate on national strategies of the one hand and the national conjuncture on the other" (Swyngedouw, 1995, p. 396).

${ }^{22}$ El préstamo tuvo tres componentes: a) componente concesión; b) componente de transformación de ECAPAG; y, c) Componente de rehabilitación de los sistemas de agua potable y de saneamiento (Díaz, 2003).
} 
Figura 1. La cronología del proceso de concesión del servicio de agua potable y de saneamiento en Guayaquil. Fuente: elaboración propia.

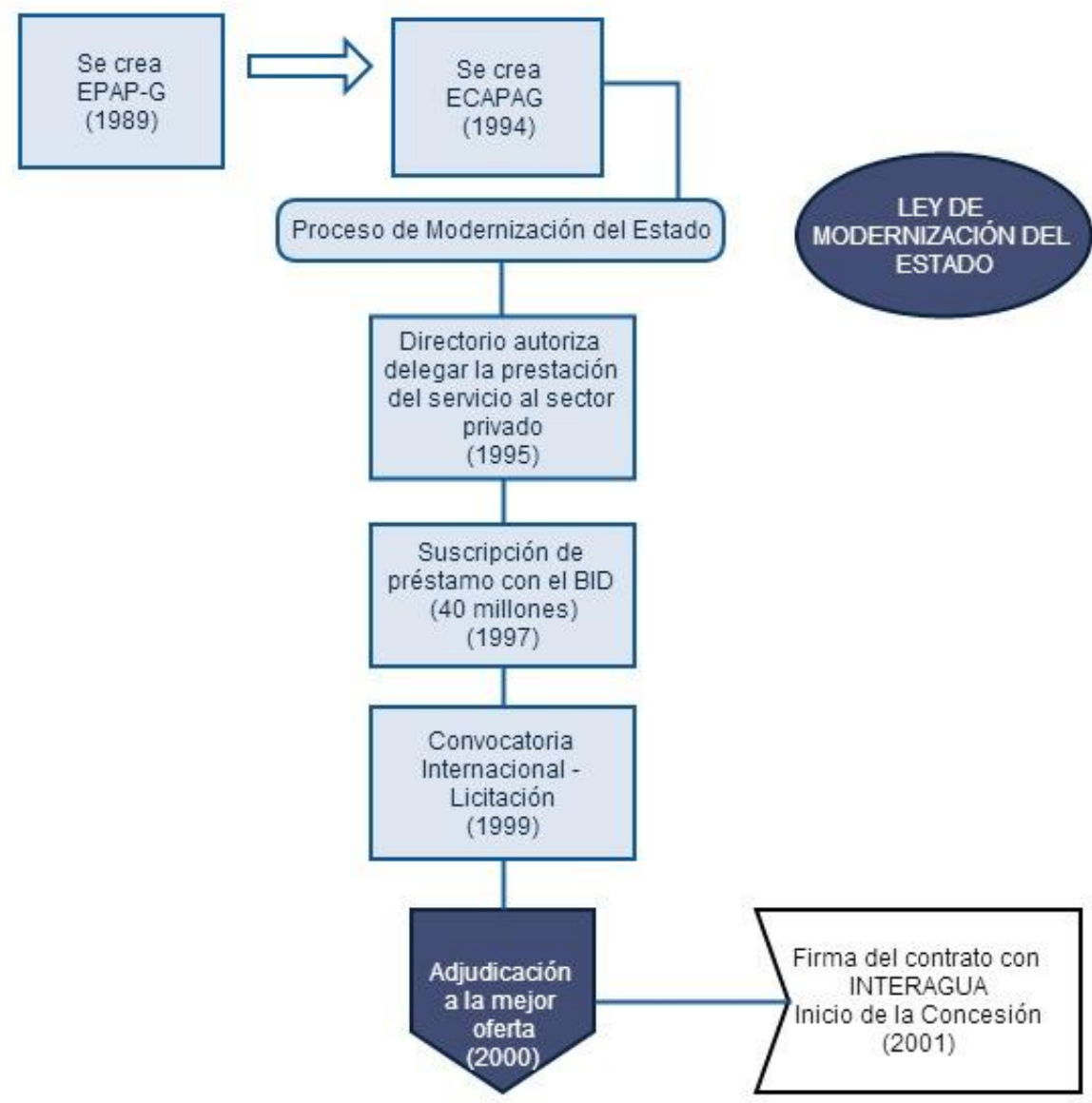

PLAZO DE CONCESIÓN (30 AÑOS)

En los 4 años siguientes, se realizó el cumplimiento de etapas del proceso de concesión, destacando entre ellas: a) la Convocatoria Internacional ${ }^{23}$ (1999); b) Precalificación oferentes (1999-2000); c) la aprobación de las bases de la licitación internacional por la Empresa, CONAM $^{24}$ y la Contraloría General del Estado (2000); d) La aprobación de las bases de la

\footnotetext{
${ }^{23}$ En diciembre de 1998, se declaró desierto el proceso convocado en febrero de 1997, sobre todo debido a dos causas: a) la inseguridad jurídica, respecto del regulador, así como el sometimiento a arbitrajes nacionales y no internacionales; y b) los requisitos técnicos (calidad, continuidad) eran muy altos. Sin embargo, como lo señala Javier Díaz (2003, p. 15), "el factor determinante para explicar el fracaso de la licitación fue el recrudecimiento de la crisis política, social y económica por la que Ecuador estaba atravesando".

${ }^{24}$ A finales del año 2000, el Director Ejecutivo del CONAM, Antonio Peré señaló: "Este proceso de concesión constituye un hito histórico en el país, y servirá como preámbulo para la realización de proyectos de igual importancia en beneficio de los ecuatorianos". (El Universo, 2005). Disponible en: http://www.eluniverso.com/2005/07/11/0001/18/18BD9B877609402E8C0616E6E71C3CD4.html_Última consulta, 17/09/2014.
} 
licitación internacional ${ }^{25}$ por el BID (2000); e) La invitación y presentación de ofertas $(2000)^{26}$; f) La adjudicación a la mejor oferta ${ }^{27}$ (2000); g) La firma del contrato de Concesión ${ }^{28}$ (2001); h) El traspaso de Servicios e infraestructura al concesionario (2001).

La decisión de la concesión fue justificada debido a las graves carencias en el sector de agua potable y alcantarillado en Guayaquil, sin embargo, el proceso para que se concretase duró más de cinco años; debido sobre todo a circunstancias de índole externo que rodearon al proceso, destacando entre ellos la inestabilidad del país (1996-2001), la crisis económica a raíz de entre otros acontecimientos del fenómeno de El Niño, y el descenso de los precios del petróleo, y la falta de seguridad jurídica que ponían en riesgo la licitación internacional. (Díaz, 2003).

\subsection{El agua en Cuenca}

Cuenca se situada entre los 2.330 y $2.500^{29}$ metros sobre el nivel del mar, m.s.n.m., sin embargo, el cantón Cuenca tiene un área de influencia con distintos pisos climáticos, que incluso llegan hasta las estribaciones de la Costa (parroquia rural de Molleturo). La ciudad se caracteriza por sus ríos ${ }^{30}$, Tomebamba, Tarqui, Yanuncay y Machángara, que le convierten en una urbe asociada al agua, debido a la presencia de importantes humedales y lagunas aguas arriba, en el sector de El Cajas, que desde 2013 es Reserva de la Biosfera de la UNESCO, al igual que el centro histórico de la ciudad que fue declarado Patrimonio de la Humanidad en 1999 (UNESCO, 2013).

El cantón Cuenca se encuentra conformado por 21 parroquias rurales, y 15 parroquias urbanas que componen el sector urbano. Su posición geográfica ha hecho que al encontrarse al Sur y alejada del bicentralismo (Quito-Guayaquil), y por ende olvidada al igual que otros territorios de Ecuador, terminó por fortalecer su sistema de gobierno local y la consecuente prestación de servicios público.

\section{a) El período precolonial}

En las crónicas de la fundación de la ciudad, en particular en las de Víctor Manuel Albornoz (1948), se señala que la zona de Paucarbamba ${ }^{31}$, fue ideal pues "lindaba por un lado con el río Tomebamba, almenado con una hilera de Tambos Reales....al Noreste con la laguna de

\footnotetext{
${ }^{25}$ A diferenciad de lo sucedido en la primera licitación fracasada, en ésta se flexibilizaron las obligaciones del futuro concesionario, sobre todo fijando metas de calidad y cobertura de manera quinquenal, así como se dio mayor libertad para el cumplimiento del compromiso de las nuevas conexiones (localización geográfica de 55.238 nuevas conexiones) (Díaz, 2003).

${ }^{26}$ Entre otras, presentaron sus ofertas las compañías: Suez Lyonnaise des Eaux y la Thames Water Overseas Limited, International Water Services, retirándose las dos primeras.

${ }^{27}$ La empresa ganadora fue International Water Services (Guayaquil Interagua C.Ltda).

${ }^{28}$ Firmado en Washington D.C., en el Banco Interamericano de Desarrollo, BID, el 11 de abril de 2001.

${ }^{29}$ Juan Cordero (2011), señala que el rango geográfico más importante de Cuenca es su altitud, debido a que si bien tiene montañas de menor elevación, estas no tienen nieves perpetuas, con lo cual se encuentran minerales metálicos y no metálicos.

${ }^{30}$ El cronista Pedro de Valverde, señala que en 1557, la ciudad de Cuenca "está poblada en un valle donde hay dos ríos (Tomebamba y Yanuncay) que la toman en medio en el más lindo asiento que hay en todo el reino".

${ }^{31}$ Juan Pablo Martínez (2014), al referirse a la historia natural de Cuenca, señala: “...el Cantón Cuenca no es solamente el extenso valle de Guapondélig o Paucarbamba, sino que llega por las estibaciones de la cordillera occidental a regiones tropicales, posee algunos de los reductos más importantes de bosque andino de esta estribación en el sur del Ecuador y es esencialmente un territorio Altoandino..."
} 
Viracochabamba"...así pues, "el asiento de Paucarbamba, es el mejor sitio por ser parte y lugar donde hay agua perpetua", situación que se vinculó de manera directa con la dotación constante de agua, no sólo por los propios ríos, sino por los cercanos páramos, cuyas montañas fueron consideradas sagradas durante el período precolombino (Turi, Cullca, etc.).

El imperio Inca se asentó en el territorio de los cañaris a mediados del siglo XV, luego de una larga batalla, pues diferencia lo que sucedía en otros territorios en los cuales los pueblos aborígenes cedían frente a la presencia de los ejércitos del Inca, en el caso de los cañaris existió una fuerte resistencia ${ }^{32}$, que les valió incluso su destierro en los barrios altos de la capital del imperio, Cuzco.

En las descripciones que el Padre Arias Dávila (1582), realiza sobre la zona en la que se asentó Cuenca, a más de los ríos y lagunas, se refiere a la de Xamenxuma, en la cual se supone que se bañaba ${ }^{33}$ el Inca, y que tenía propiedades medicinales, y que por otro lado destacaba por tener una gran calidad de agua.

Pese al poco tiempo que estuvieron los incas en la zona, no se debe olvidar que Tomebamba o Tumipamba ${ }^{34}$ fue la segunda capital del imperio, y la preferida del Inca Tupac Yupanqui, en ella se replicaron las técnicas de conducción de agua a través de canales, para su distribución en las ciudadelas, y templos, situación que será aprovechada posteriormente por los conquistadores para proveerse de líquido vital.

\section{b) El período colonial y el republicano}

La fundación española fue realizada por Gil Ramírez Dávalos, ciudad escogida por su territorio, ya que, de acuerdo a la legislación vigente a la fecha, era necesario el cumplimiento de unas características especiales para la fundación de nuevas ciudades en América hispana, tanto la traza urbana que replicaba la española, y también el agua, pues eran necesaria la presencia de agua corriente (Cordero, 2011).

Gracias a la riqueza de recursos hídricos con los que contaba la zona, no sólo se tenía acceso de fuentes de agua naturales para el consumo humano, sino que también fueron utilizadas para otros fines como para los molinos.

Además de las fuentes de agua cercanas (ríos), contribuyó de manera particular a la higiene y mantenimiento de acequias de la ciudad, el hecho de que la misma tengan un particular declive ${ }^{35}$

\footnotetext{
${ }^{32}$ El cronista de la ciudad, al respecto señala: "Se sabe que resistieron, a la medida de sus posibilidades, a la invasión incaica, pero al sentirse impotentes ante su incomparable poderío militar llegaron a capitular, hacia mediados del siglo XV, para convertirse en sus leales aliados, con prestación de servicios en el Cuzco..." (Cordero, 2011, p. 22).

${ }^{33}$ El historiador, Padre Juan de Velaso en su obra Historia del Reino de Quito en la América Meridional (1959), al referirse a las aguas termales dice: "llámese a este pueblo de los Baños, por lo que tiene aguas termales, las cuales salen hirviendo en una gran extensión de terreno casi llano, por más de trescientos ojos - ahora son esos muy pocos-, y forman un pequeño río -El Salado-."

${ }^{34}$ El inca Garcilaso de la Vega al referirse a Tomebamba como segunda capital del incario, dice: "Túpac Yupanqui y después su hijo Huayna Cápac ennoblecieron mucho esta provincia de los cañaris y la que llaman Tumipampa, con edificios y casas reales, entapizados los aposentos con yerbas, plantas y animales contrahechos al natural de oro y plata: las portadas estaban chapadas de oro, con engastes de piedras finas, esmeraldas, turquesas..." (En Cordero, 2011).

${ }^{35} \mathrm{Al}$ referirse a las calles de la ciudad de Cuenca, FJ. Caldas señala "todas las que corren de oriente a occidente tienen acequias de agua abundante que facilitan el aseo. Este pueblo tiene la ventaja sobre muchos: el agua puede llevar a todos los puntos de la ciudad". (En Ordóñez, 2008, p. 21).
} 
que permitía que las aguas del río Tomebamba (Julián Matadero), corra por toda la ciudad, permitiendo su uso en labores agrícolas, de higiene y de embellecimiento de jardines.

A mediados del siglo XVIII, la Administración Pública Colonial (Cabildo), impulsó obras de infraestructura relativas a la dotación de agua para la ciudadanía, entre las que destacan tanto la reconstrucción de la pileta pública ${ }^{36}$ de la plaza mayor, y la conducción desde ésta de agua para el hospital Real (Cordero, 2011).

Situación que es corroborada por el explorador Teodoro Wolf (1892), quien, al describir Cuenca como la segunda ciudad en importancia del interior y tercera de la República, hace una especial referencia a que en medio de la plaza mayor existe una fuente y un jardín.

A inicios del siglo XIX ${ }^{37}$ (1802), cuando Alejandro Humboldt llega a la ciudad de Cuenca, describe la situación de los ríos de la siguiente manera: "Cuenca está situada entre tres ${ }^{38}$ pequeños ríos: al norte el Machángara, al sur el río de Matadero y más al sur el río Yanuncay. Todos van al río Paute. El Yanuncay es el más curioso. Tiene la masa de agua más oscura (café claro) y de un verde amarillento claro en pequeñas porciones, semejantes al río Negro". (En Cordero, 2011, p. 51).

\section{c) El período de intervención municipal}

Un aspecto interesante de la titularidad pública de las aguas se puede observar en las actas del Cabildo, a inicios del siglo XX, cuando un sinnúmero de ciudadanos pide el uso gratuito de las aguas del río (Sayausí), situaciones que fueron denegadas, ya que el Municipio era su titular, pese a que los vecinos querían desconocer tal singularidad al Concejo.

Existen una serie de acontecimientos relacionados a la preocupación que da el ente municipal respecto del abastecimiento de agua y alcantarillado por parte del Municipio cuencano (Ordóñez Espinoza, 2008).

A inicios del siglo XX, fue casi nula la presencia municipal en la dotación de servicios básicos, concentrándose más en aquellos que daban "vistosidad a la ciudad"39, De esta forma, entre 1914

\footnotetext{
${ }^{36}$ Según consta en los archivos del Cabildo, el proyecto de la pileta pública inició en 1586, con el objetivo que esté a disposición de todos los vecinos. Para lo cual se traería agua del molino de D. Pedro Fernández. Sin embargo, tuvieron que pasar muchas décadas para que la construcción definitiva de la pileta, pese a las presiones del clero, quienes incluso aportaron importantes cantidades de dinero.

${ }^{37}$ Sin embargo, no todos veían de manera positiva la higiene y el saneamiento de la ciudad, de esta manera Fray Vicente Solano (1791-1865), realiza la siguiente crítica: "Cuenca se parece a una ciudad asiática con relación a su desaseo. Por doquiera que se extienda la vista se hallarán bascosidades; las calles son las letrinas del populacho: las acequias que reciben las basuras de las casas no corren con libertad; las que están fuera de las habitaciones principales contienen un fango que jamás se limpia: la acequia que llaman del Gallinazo pone el cúmulo de todos los principios de corrupción, por ser el depósito de todas las inmundicias de las casas contiguas y porque la poco agua que corre no es suficiente para limpiarlas". Fuente: Revista Avance, Edición No. 266, enero de 2014. Disponible: $\quad$ http://www.revistavance.com/varios-enero-2014/etapa-46-anos-de-calidad-en-la-vida-de-loscuencanos.html, último acceso: 18/11/2014.
}

\footnotetext{
${ }^{38}$ Nótese que el explorador no hace referencia al río Tarqui, pues en ese entonces se encontraba fuera de los límites de la ciudad.

39 "Hasta inicios de la segunda mitad del siglo XX, las obras de agua y alcantarillado... no gustaban a los políticos quienes preferían la vistosidad de las vías, pavimentación y puentes y hasta energía eléctrico... sin embargo, las
} 
y 1915, se debe destacar la presencia y la obra del Municipio de la ciudad en la dotación de los servicios públicos, primero con la instalación de la hidroeléctrica de Yanuncay, y posteriormente con la primera intervención en las aguas que venían del río Sayausí, permitiéndose separar "las aguas en distintos colectores que corrían por la misma región Norte de la ciudad". (Ordóñez, 2008). Pues hasta la fecha, fue más la participación de la iniciativa privada la que permitió de la dotación a la ciudadanía de algunos servicios públicos como energía eléctrica y posteriormente los teléfonos.

Con respecto al saneamiento, el panorama era poco alentador, pues como lo relata Ordóñez (2008, p. 29-30): “...todas las calles contaban con una acequia cuyas aguas corrían de occidente a oriente...en cuyas aguas se arrojaban todas las basuras que producían, como era natural olores desagradables, especialmente durante las primeras horas de la mañana y por las noches, horas que salían los sirvientes a asear los bacines". Si bien es cierto la cobertura del servicio de agua se iba ampliando, aún hasta mediados del siglo XX se mantuvieron los grifos públicos en la ciudad.

Una vez terminada la revolución de 1944, la reorganización municipal contribuyó al progreso de la urbe, se construyó múltiples infraestructuras, en particular aquellas relacionadas con los servicios básicos (canalizaciones), y fue precisamente durante esos años que se realizó el primer plan regulador de la ciudad (ordenamiento territorial) (Cordero, 2011), fundándose posteriormente, en 1947 la división de agua potable manejada directamente por el Municipio, y fue recién a mediados del siglo XX, cuando se manda a tapar las acequias de la calle principal de la ciudad.

El año de 1949, fue crucial en la provisión de servicios públicos para la ciudad de Cuenca, se da la creación de la Empresa autónoma de Luz, Agua y Teléfonos, EMLAT.

Un hecho particular, relacionado con las tarifas de agua potable, se presenta primero entre 1945$1950^{40}$, respecto a la supuesta gratuidad del agua al tratarse de "un regalo de Dios y la Naturaleza", y que en consecuencia mal podría cobrarse (Ordóñez, 2008), y que fue complementada en 1958, cuando los usuarios ciudadanos se sienten afectados por los elevados costos del nuevo pliego tarifario, que obligó a suspender su aplicación.

La EMLAT estuvo vigente tan sólo 15 años, de 1949 hasta 1964, pues fue derogada debido a razones laborales y técnicas, que obligaron a que la competencia de agua potable, saneamiento y teléfonos sea reasumida por el Municipio de Cuenca (Avance, 2014). Sin embargo, como bien lo señala Manuel Neira Carrión (2011) ${ }^{41}$, que el Ayuntamiento conservó "las secciones de agua potable y de teléfonos con la misma estructura administrativa y el mismo personal”.

La prestación del servicio de agua potable y teléfonos por parte del Municipio de manera directa, tan sólo se mantuvo cuatro años, pues entre 1968 y 1969, respectivamente, fueron años decisivos en la historia de la gestión del agua potable y alcantarillado en Cuenca, pues primero

\footnotetext{
obras enterradas no dan aparentemente ningún crédito ni rédito político, con lo que las asignaciones presupuestarias para ese fin eran escasas". (Ordóñez, 2008, p. 41).

40 "Muchos critican el sistema de abastecimiento y dicen que el agua es un regalo de Dios y de la Naturaleza y que no se debe cobrar por el agüita..." (Ordóñez, 2008, p. 44).

${ }^{41}$ Véase: “Aniversario de ETAPA”, Manuel Neira Carrión (2011). En Diario El Tiempo

Disponible en: http://www.eltiempo.com.ec/noticias-opinion/3681-aniversario-de-etapa/, último acceso: $18 / 11 / 2014$.
} 
se creó la Empresa Municipal de Teléfonos, Agua Potable y Alcantarillado, ETAPA, ${ }^{42}$; y al año siguiente, se aprobaron los primeros Planes Maestros de Agua Potable y Alcantarillado ${ }^{43}$ (Cordero, 2011) (Ordóñez, 2008).

En las siguientes décadas, ETAPA experimentó grandes cambios a la par que la ciudad se desarrollaba, es por ello que durante este tiempo se planificó y ejecutó los primeros Planes Maestros de agua potable y saneamiento, que fueron complementados en su segunda fase ya en la década de los noventa y que reflejaban una Empresa mucho más dinámica y sobre todo planificadora y responsable del desarrollo equilibrado y ordenado de una ciudad moderna con servicios públicos.

\section{El agua en Ecuador: realidad y perspectivas a futuro}

El texto constitucional de 2008 fue el primero en reconocer de manera explícita al agua como un derecho humano fundamental, lo cual le otorga una categoría especial, y sobre todo revela la importancia que se le da en la nueva construcción del Estado, lo cual concuerda con la realidad geográfica del país (Martínez, 2017).

En el art. 3, numeral primero, se establecen los deberes primordiales del Estado, en el cual se reconoce y garantiza sin discriminación el goce de entre otros derechos, al del agua para sus ciudadanos, y lo cual se desarrolla en el capítulo segundo, del Título II, que se refiere a los Derechos del Buen Vivir. En el art. 12, se reconoce ya el derecho humano al agua como fundamental e irrenunciable.

En el texto constitucional ecuatoriano, se da la categoría al agua de patrimonio nacional estratégico, así como se le otorga unas características especiales que serán incompatibles con su explotación o uso, pues se dice que será de uso público, inalienable, imprescriptible, inembargable y esencial para la vida.

El texto constitucional al referirse al derecho a la salud (art. 32), señala claramente que este derecho se encuentra relacionado con otros que forman parte de ese círculo virtuoso que es el buen vivir o sumak kawsay, entre los cuales se destaca el derecho al agua. Situación confirmada en el numeral segundo del art. 66 cuando se habla del derecho a la vida digna de las personas, donde un elemento central para que se dé la misma es la provisión de "agua potable" (Martínez, Aguilar \& Verdugo, 2018).

Existe prohibición expresa respecto de la privatización ${ }^{44}$, tanto del agua como de sus fuentes, situación que tuvo que ser regulada sobre todo por influencia de las comunidades y pueblos indígenas, así como montubios, debido a la acumulación del líquido vital por parte de particulares y compañías, quienes dados sus ingentes recursos pudieron almacenar gran cantidad de agua, dejando sin sustento para el riego de los huertos agrícolas de los colectivos más desprotegidos.

\footnotetext{
${ }^{42}$ Bajo el argumento que era: “de absoluta necesidad el administrar financiera y técnicamente de manera autónoma los servicios de agua potable, alcantarillado y teléfonos de la Ciudad y sus parroquias”, el Concejo Cantonal crea la nueva empresa municipal.

${ }^{43}$ Gracias a un contrato con el Instituto Ecuatoriano de Obras Sanitarias, IEOS, de reciente creación.

44 “...las luchas sociales contra la privatización de los sectores estratégicos como el agua en varios países, es una evidencia de que amplios sectores - sobre todo populares- están saturados de la explotación privada de bienes públicos que sustentan lo público" (Carpio, 2009, p. 140).
} 
El art. 282, de la mencionada norma, señala que "El Estado regulará el uso y manejo del agua de riego para la producción de alimentos, bajo los principios de equidad, eficiencia y sostenibilidad ambiental".

La provisión de agua potable, así como agua de riego, es una responsabilidad exclusiva del Estado Ecuatoriano, pues se trata de un sector "estratégico" (Constitución del Ecuador, 2008, art. 313-314), siendo competencia exclusiva de los gobiernos municipales, entre otras, la prestación del servicio de agua potable, alcantarillado y depuración de aguas residuales.

La Constitución en su art. 318, definió al agua como "patrimonio nacional estratégico" y determinó de forma restrictiva que su uso, el cual es público, así como le atribuyó las características de inalienable e imprescriptible, y cuya gestión puede ser pública (gobiernos locales), o comunitaria (asociaciones de usuarios, campesinos, pueblos originarios o indígenas).

El Estado se reservó para sí el derecho de administrar, regular, controlar y gestionar los sectores estratégicos, entre los que se encuentra el agua (art. 313). Siendo por lo tanto el Estado el responsable de la provisión de los servicios públicos de agua potable y saneamiento (art. 314).

Sin embargo, de conformidad con el art. 260, el ejercicio de las competencias exclusivas, entras las que se encuentran la gestión de los recursos hídricos, no excluirá la concurrencia en la gestión en la prestación de servicios públicos, para lo cual se complementará con otros niveles de gobierno. Situación que también la Ley Orgánica de Recursos Hídricos, Uso y Aprovechamiento del agua, LORHUAA, ha previsto en su primer artículo, al señalar que los recursos hídricos serán gestionados de manera concurrente entre el Gobierno Central y los Gobiernos Autónomos Descentralizados.

La prestación del servicio de agua potable, alcantarillado y depuración de aguas residuales es una competencia exclusiva de los gobiernos municipales de acuerdo a la disposición constitucional constante en el art. 264.

El Código Orgánico de Ordenamiento Territorial y Administración Descentralizada (2010), en su art. 55, contempla como competencia exclusiva de los gobiernos autónomos descentralizados municipales, la prestación del servicio de agua potable, alcantarillado, depuración de aguas residuales y saneamiento ambiental.

La misma norma, en el art. 137, dentro de la regulación para el ejercicio de las competencias de prestación de servicios públicos, definió que los servicios de agua potable en todas sus fases la realizarán los municipios, mientras que aquellos que se presten en las parroquias rurales deberán ser coordinados con las juntas parroquiales, lo cual también se encuentra previsto en el último inciso de la LORHUAA.

Cabe señalar que, si bien es cierto que son los gobiernos municipales los encargados de la prestación del servicio público de agua potable y saneamiento, muchos de ellos a fin de tener un servicio eficaz, eficiente y de calidad, han optado por la prestación a través de las Empresas Públicas Municipales Autónomas, las cuales se fundamentan en la Ley Orgánica de Empresas Públicas y el COOTAD. 
Sin embargo, en los cantones pequeños debido a su estructura, el servicio se sigue prestando de manera directa por parte del Municipio ${ }^{45}$.

\section{Conclusiones}

Los últimos datos en relación con el abastecimiento de agua potable y saneamiento en Ecuador son alentadores, $92 \%$ y $86 \%$, respectivamente, sin embargo, una de las particularidades que se presenta es la brecha entre lo urbano y lo rural. En el presente trabajo se demuestra también en relación a las grandes ciudades-regiones, las cuales concentran gran cantidad de la población, no obstante, la situación en los pequeños poblados es distinta no solo en relación a acceso a agua, sino sobre todo a calidad (agua segura), situación que se relaciona con el sexto de los Objetivos de Desarrollo Sostenible, pues según datos del Banco Mundial, la Organización Mundial de la Salud y el Instituto de Estadísticas y Censos del Ecuador, tan solo el $79 \%$ del agua que se consume en Ecuador es segura ${ }^{46}$.

Al igual que sucede en otros países, el caso de Ecuador no es la excepción en relación al modelo de gestión para el abastecimiento de agua, pues si bien es cierto los modelos públicomunicipales han operado de manera eficiente en las ciudades de los Andes, el caso de Guayaquil explica que el modelo privado-concesionario pero con la tutela del gobierno local, es eficiente con altos niveles de cobertura, con lo cual no se puede afirmar que un esquema es el correcto, sino que los mismos se adaptan a las realidades de las ciudades.

Si bien es cierto, Ecuador triplica la media internacional de acceso a fuentes de agua, es fundamental que se trabaje en campañas de educación ambiental y protección de las fuentes hídricas, ya que de esto depende el futuro de la provisión del servicio bajo un principio intergeneracional.

Solo de esta manera los ecuatorianos mantendrán vigente esa interesante relación que han tenido con el agua y los recursos naturales, que viene desde los pueblos aborígenes y a lo largo de su historia se ha adaptado a cada una de las culturas que han ocupado su territorio, con el propósito de garantizar el acceso al líquido vital.

\section{Referencias}

Albornoz, Víctor Manuel. (1948). Monografía histórica de Cuenca. Cuenca: Editorial Austral.

Andrade, Xavier. (2007). Guayaquil: Diario de una ecología privatizada. Revista Nueva Sociedad, 212, 134-147.

\footnotetext{
${ }^{45}$ El Banco Mundial (2005), señala que en las mayor parte de las cabeceras cantonales el servicio de agua potable sigue prestándolo directamente el municipio a “... a través de departamentos municipales, cuyo personal se comparte muchas veces con otras actividades y cuyos ingresos y gastos se confunden con los de la caja común del municipio". Con lo cual, es poco el control que se puede tener, así como resulta dificultoso alcanzar eficiencia en la prestación del servicio si la Institución no goza de un buen estado financiero que le permita invertir en nueva infraestructura, así como otorgar un mantenimiento adecuado al sistema.

${ }^{46}$ Disponible en: https://www.ecuadorencifras.gob.ec/documentos/web-

inec/Bibliotecas/Libros/AGUA,_SANEAMIENTO_e_HIGIENE.pdf, último acceso: 9/07/2019.
} 
Carpio Benalcazar, Patricio. (2009). El buen vivir más allá del desarrollo. La nueva perspectiva Constitucional del Ecuador. En A. Acosta y E. Martínez (Coord.), El Buen Vivir. Una vía para el desarrollo. Quito: Ediciones Abya-Yala.

Carrillo, P., Bellettini, O. y Coombs, E. (2007). Stay Public or Go Private?: a Comparative Analysis of Water Services between Quito and Guayaquil. Working Paper, 223. Washington: IDB.

Cordero Iñiguez, Juan Cordero. (2011). Signos de identidad cuencana. Cuenca: Municipio de Cuenca.

Díaz, Javier. (2003). La participación del sector privado en los servicios de agua y saneamiento en Guayaquil, Ecuador. Washington, D.C.: Banco Interamericano de Desarrollo.

Donoso Gaibor, Mónica. (1998). Evaluación rápida de las condiciones de saneamiento básico en zonas urbano marginales de la ciudad de Guayaquil - Ecuador. La Paz: Programa de Agua y Saneamiento PNUD - Banco Mundial, Regional Andina.

Fuentes Roldán, Alfredo. (2007). Quito: Tradiciones. Tomos I y II. Quito: Abya Yala.

Huanacuni Mamani, Fernando. (2010). Vivir Bien/Buen Vivir. Filosofía, políticas, estrategias y experiencias regionales. La Paz: Instituto Internacional de Integración (III-CAB).

Instituto Geográfico Militar, IGM. (2013). Atlas Geográfico de la República del Ecuador, II Edición. Quito: Instituto Geográfico Militar \& Secretaría Nacional de Planificación y Desarrollo.

Jarrín, Carlos \& Landazuri, Cristóbal. (2014). Fenómenos naturales en la meseta de Quito. En Alfonso Ortíz Crespo, Historia del agua en Quito (pp. 95-101). Quito: EPMAPS EP.

Kennedy Troya, Alexandra. (2005). Imágenes de Identidad. Acuarelas Quiteñas del Siglo XIX. Quito: Fondo de Salvamento del Patrimonio Cultural, FONSAL.

Kingman Garcés, Eduardo. (2006). La ciudad y los otros Quito 1860-1940. Higienismo, ornato y policía. Quito: FLACSO.

Luzuriaga Jaramillo, Sofia. (2014). El cabildo colonial quiteño: regente del agua. En Alfonso Ortíz Crespo, Historia del agua en Quito (pp. 154-171). Quito: EPMAPS EP.

Llasag Fernández, Raúl. (2008). Plurinacionalidad: una propuesta constitucional emancipadora. En Ramiro Ávila Santamaria (Ed.), Neoconstitucionalismo y Sociedad. Quito: Ministerio de Justicia y Derechos Humanos.

Martínez Moscoso, Andrés. (2017). El Derecho al Agua en el Ecuador. Una visión desde la Ciencia Política y el Derecho Público. Cuenca: Universidad de Cuenca.

Martínez Moscoso, A., Aguilar Feijó, Víctor \& Verdugo Silva, Teodoro. (2018). The Vital Minimum Amount of Drinking Water Required in Ecuador. Resources, 7 (1), 15. http://dx.doi.org/ 10.3390/resources7010015 
Martínez Moscoso, Juan Pablo. (2014). El manejo de cuencas como una forma de apego al territorio. Diario El Mercurio (29 de mayo de 2014).

Ordóñez Espinosa, Galo. (2007). Agua Potable en Cuenca. Una historia reciente. Revista Galileo de la Facultad de Ingeniería de la Universidad de Cuenca, 19, 18-20.

Ordóñez Espinosa, Galo. (2008). De la bacinilla a la alcantarilla. Cuenca: Uediciones, Universidad de Cuenca.

Ortiz Batallas, Cecilia. (2014). El agua condición del hábitat moderno (1830-1960). En Alfonso Ortíz Crespo. Historia del agua en Quito (pp. 242-251). Quito: EPMAPS EP.

Ortíz Crespo, Alfonso (2014). Historia del agua en Quito. Quito: EPMAPS EP.

Pigretti, Eduardo A., Bellorio Clabot, Dino \& Cavalli, Luis. (2010). Derecho ambiental de aguas. Buenos Aires: Laujane Editores.

Pérez, Efraín. (2009). Derecho Administrativo, Tomos I y II. Quito: Corporación de Estudios y Publicaciones.

Quiroga Lavié, Humberto. (1991). Derecho Constitucional Latinoamericano. México D.F.: Universidad Autónoma de México.

Swyngedouw, Erik A. (1994). The contradictions of urban water provision: A study of Guayaquil, Ecuador. Third World Planning Review, 17 (4), 387-405.

Wolf, Teodoro. (1976). Geografía y Geología del Ecuador. Quito: Casa de la Cultura.

Zary, Julio. (2009). ¡El Agua! y Quito. Quito: Editorial El Conejo. 